\title{
TREND PERALIHAN ARTIS TELEVISI MENJADI YOUTUBE CONTENT CREATOR
}

\section{Elsa Maghfira Paramesti ${ }^{1}$, Syifa Syarifah Alamiyah ${ }^{2}$, Fitrania Yunsafa Cahayani ${ }^{3}$}

${ }^{1-3}$ Universitas Pembangunan Nasional Veteran Jawa Timur

Elsamaghfira1801@gmail.com ${ }^{1}$, syifa_syarifah.ilkom@upnjatim.ac.id ${ }^{2}$, fcahayani@gmail.com ${ }^{3}$

\section{Article Info}

\section{Article history:}

Received 17 Juni 2021

Accepted 5 Agustus 2021

Published 1 Oktober 2021

\section{Keyword:}

Youtube, Televisi, Mahasiswa, Konten kreator

\begin{abstract}
Youtube is one of the social media that is currently trending and provides space for everyone to convey their creative ideas. Youtube also provides feedback in the form of Adsense for content creators who have interesting videos and are seen by many people. This study discusses students' perceptions of the trend of transitioning television artists into youtube content creators. The purpose of this study was to determine students' perceptions of the transition from television artists to youtube content creators. This research method uses qualitative research with audience analysis. The results of this study indicate that students' perceptions of the transition from television artists to YouTube content creators are natural, especially supported by increasingly advanced information technology. It provides an opportunity for everyone as a means to develop soft skills. Meanwhile, the uploaded content must have good value and quality, so that it can get appreciation from many people. Besides that, the perspective of students in accessing information and entertainment prefers YouTube, because it is more effective and practical to reach audiences in a short time.
\end{abstract}

Youtube merupakan salah satu media sosial yang saat ini sedang trending dan memberikan ruang bagi semua orang untuk menyampaikan ide kreatifnya. Youtube juga memberi feedback berupa Adsense bagi conten creator yang memiliki video menarik dan dilihat oleh orang banyak. Penelitian ini membahas tentang persepsi mahasiswa tentang trend peralihan artis televisi menjadi youtube content creator. Tujuan penelitian ini adalah untuk mengetahui persepsi mahasiswa mengenai peralihan artis televisi menjadi youtube content creator. Metode penelitian ini menggunakan jenis penelitian kualitatif dengan analisis audience.

Hasil dari penelitian ini menunjukkan bahwa, persepsi mahasiswa tentang beralihnya artis televisi menjadi youtube content creator merupakan kewajaran, apalagi didukung dengan teknologi informasi yang semakin maju. Hal itu memberikan kesempatan kepada semua orang sebagai sarana untuk mengembangkan soft skill. Sedangkan content yang diupload harus memiliki value yang baik dan berkualitas, agar bisa mendapatkan apresiasi dari orang banyak. Disamping itu perspektif mahasiswa dalam mengakses informasi dan hiburan lebih memilih youtube, karena lebih efektif dan praktis untuk menjangkau khalayak dalam waktu singkat.

Copyright (C) 2021 Jurnal Ilmu Komunikasi. All rights reserved.

Editorial Office:

Program Studi Ilmu Komunikasi, Fakultas Dakwah dan Komunikasi, UIN Sunan Ampel Surabaya.

Jl. Ahmad Yani 117 Surabaya, Jawa Timur, Indonesia.

Email: jurnalilkom@uinsby.ac.id 


\section{Pendahuluan}

kehadiran media baru pada saat ini telah melahirkan pergeseran pada media tradisional seperti Televisi ${ }^{1}$. Televisi merupakan salah satu media komunikasi masyarakat dalam bentuk audio visual yang populer di kalangan masyarakat ${ }^{2}$ berpendapat bahwa televisi juga seharusnya mampu menawarkan gaya hidup baru, style terbaru bahkan perilaku baru yang sebelumnya tidak dikenal di kalangan masyarakat. ${ }^{3} \quad$ Memaparkan Televisi di layar kaca televisi sangat berpengaruh pada program yang ditayangkan. Program televisi akan menentukan keberhasilan program yang disampaikan. Hal ini disebabkan karena peran dan fungsinya sangat jelas sebagai media massa yang mampu memberikan kontribusi bagi kebutuhan masyarakat akan informasi dan hiburan. Namun pada zaman sekarang media televisi mulai bersaing dengan kehadiran youtube karena, kehadiran youtube membawa pengaruh luar biasa kepada masyarakat, khususnya bagi kalangan mahasiswa Ilmu Komunikasi UPN Veteran Jawa Timur yang memiliki gairah di bidang pembuatan video atau menjadi konten creator. Youtube menjadi media sosial yang diminati oleh masyarakat Indonesia,

${ }^{1}$ T.S, Andrea Prayoga, Farid. " Analisis Minat Pelanggan Konten Musik Video Pada Channel Youtube Eclat Story." Prologia, 2 No. 2 (2018): 243-249.

${ }^{2}$ Winda, Makal. “ Persepsi Orang Tua Tentang Tayangan Upin Ipin MNC TV Dalam Penggunaan Bahasa Melayu Pada Masyarakat Kelurahan Taratara 2 Kecamatan Tomohon Barat." Jurnal acta diurna komunikasi, 1 No.3 (2019): 1-12

3 Rahayu, Puji Diah. "Persepsi Masyarakat Terhadap Etika Komunikasi Pembawa Acara Berita Tepian TV Dalam Memberikan Pesan Berita dikarenakan sudah banyak konten creator yang semakin kreatif untuk membuat konten pada channelnya.

YouTube merupakan platform yang berbagi video (video sharing) yang memungkinkan pengguna untuk secara gratis mengunggah, menonton dan berbagi tayangan video. ${ }^{4}$ Salah satu layanan dari google ini, memfasilitasi penggunanya untuk mengunggah video dan bisa diakses oleh pengguna yang lain dari seluruh dunia secara gratis. Youtube sebagai ekspresi, eksistensi diri dan kebebasan diri kaum muda yang digunakan untuk mengembangkan jaringan dan keluar dari keluar dari perasaan terkurung. Identitas kaum muda yang dihadirkan di Youtube mencerminkan diri kaum muda sebagai kaum muda Indonesia adalah kreatif, eksis, narsis, bebas, dan ekspresif. $^{5}$ Bisa dikatakan Youtube dalam masyarakat disebabkan karena kaum muda membutuhkan "Dunia Baru", yaitu dunia tempat anak muda melepaskan diri dari keseharian, dan sebagai tempat menyalurkan ekspresi dan medianya mudah dan murah untuk diakses. Saat ini Youtube dalam masyarakat sebagai medium penyaluran hobi dan eksistensi diri. Youtube menjadi media sosial yang dilirik oleh masyarakat Indonesia,

Kepada Masyarakat Seputar Kota Samarinda." $e$ Journal Ilmu Komunikasi, 3 No. 3, (2015):185 198.

${ }^{4}$ Faiqah, Fatty, Nadjib, Muh, Amir, Andi Subhan. "Youtube Sebagai Sarana Komunikasi Bagi Komunitas Makassarvidgram." Jurnal Komunikasi KAREBA, 5 No.2 (2016):259-272.

5 Fahdal, Soraya, Nurhajati Lestari. “ Identifikasi Identitas Kaum Muda di Tengah Media Digital (Studi Aktivitas Kaum Muda Indonesia di Youtube) ." Jurnal AL-AZHAR INDONESIA SERI PRANATA SOSIAL, 1 No.3 (2012): 176-200. 
dikarenakan sudah banyak Konten creator yang tercipta di Youtube dan menjadi referensi bagi pengguna baru.

Pemanfaatan new media kini semakin meningkat menjadikan banyaknya artis dan influencer untuk mengambil keputusan dari media televisi beralih ke youtube karena tidak selamanya artis televisi dapat bertahan di industri pertelevisian. Youtube saat ini digunakan untuk menjadikan tempat yang menunjukan karya dan kreativitas yang mereka punya. Dimana mereka berlombalomba untuk menjadi konten creator dengan tujuan untuk menghibur bagi penggemarnya. ${ }^{6}$ Banyak dari konten creator atau artis televisi yang baru memasuki dunia youtube yang videonya berisi mengenai kegiatan yang bersifat pribadi maupun pengetahuan yang dapat memberikan manfaat ilmu pagi penontonnya. Youtube sangatlah berpotensi untuk meenyebarluaskan karya atau kreativitas. Nilai tambah dari hasil pembuatan karya di youtube adalah Adsense. Dari iklan atau Adsense tersebutlah content creator dapat menghasilkan uang bahkan dalam jumlah yang banyak. $^{7}$

Oleh karena itu, persepsi mahasiswa mengenai artis televisi ini penting, karena dapat dipahami bahwa dengan banyaknya artis televisi beralih dari televisi sebagai youtube konten creator adalah sebagai ajang untuk menghibur, menyalurkan

\footnotetext{
${ }^{6}$ Winda, Makal. “ Persepsi Orang Tua Tentang Tayangan Upin Ipin MNC TV Dalam Penggunaan Bahasa Melayu Pada Masyarakat Kelurahan Taratara 2 Kecamatan Tomohon Barat." Jurnal acta diurna komunikasi, 1 No.3 (2019): 1-12

7 Saputri, Fiqih Hana. "Pembuatan Dokumenter Mengenai Keberhasilan Pemanfaatan Youtube
}

kreatifitasnya serta mendapat penghasilan yang lebih menjanjikan di masa yang akan datang. Pada perkembangan hiburan saat ini banyak perusahaan menggunakan media sosial youtube untuk memberikan semacam tutorial, iklan dan review produk yang dilakukan oleh artis yang beralih profesi sebagai youtube konten creator adalah ajang untuk menambah penghasilan serta membawa pengaruh yang signifikan pada keberlangsungan perkembangan youtube pada era saat ini, yang nanti nya memberikan dampak yang baik juga pada minat penonton untuk eksistensi pada youtube itu sendiri. Karena artis sendiri memiliki image atau nama yang baik di industri hiburan. Pada hakekatnya dengan adanya artis televisi yang berubah menjadi youtube konten creator justru memberi pandangan, gambaran serta persepsi pada kita bahwa pada saat ini tidak semua artis dapat bertahan di industri pertelevisian saat ini yang masih sangat dibatasi banyak hal dan akhirnya mereka memproduksi sendiri isi konten nya dalam youtube.

\section{Televisi dan Industri Hiburan}

Menurut Chairil Ansyorie yang dimaksud dengan televisi adalah sistem elektronik yang mengirimkan gambar hidup bersama suara melalui kabel. ${ }^{8}$ Sedangkan menurut Andreas Dwi Atmoko, Televisi merupakan salah satu media massa yang berpengaruh terhadap perilaku anak terutama dalam proses penyerapan

Sebagai Mata Pencaharian Melalui Konten Kreatif."Jurnal Sisfotek Global, 10 No. 2 (2020): 12 8 Ansyorie, Chairil, Marwan, Azhar, Khairil Buldani. "Pengaruh Tayangan Talkshow "Indonesia Lawyers Club" Terhadap Pendidikan Politik Mahasiwa". Jurnal Professional FIS UNIVED, 6 No.2 (2019): 59-67 
(internalisasi) nilai-nilai sosial tertentu Sistem ini menggunakan peralatan yang mengubah cahaya dan suara ke dalam gelombang elektrik dan mengkonversikannya kembali ke dalam cahaya yang dapat dilihat dan suara yang dapat di dengar. ${ }^{9}$ Menurut Kuswandi dalam Syarief, televisi dapat menguasai ruang dan jarak, mencapai sasaran yang sangat luas, memiliki nilai aktualisasi terhadap suatu pemberitaan dan informasi yang sangat cepat, serta bersifat audiovisual sehingga meningkatkan daya Perkembangan televisi di Indonesia saat ini berkembang secara pesat serta khalayak aktif menjadikan televisi sebagai salah satu alat kontrol masyarakat. Perkembangan pertelevisian di Indonesia sudah semakin dahsyat sehingga mampu mengubah pola pikir dan nilai-nilai ditengah masyarakat. Media televisi saat ini juga sudah beralih fungsi, semula televisi hanya digunakan sebagai media informatif dan entertaining, namun saat kini televisi menjadi sarana peluang bagi mereka yang memiliki minat di bidang media massa untuk dapat menyalurkan bakatnya di industri pertelevisian. Perkembangan industri hiburan di Indonesia saat ini terbilang sangat pesat terbukti dengan adanya berbagai macam industri yang telah maju, negara Indonesia merupakan negara yang memiliki peranan aktif dalam industri

\footnotetext{
${ }^{9}$ Putra, Mardhan Kurniawan." Pengaruh Tayangan Berita Jurnal Sore Di Esa Tv Terhadap Kepuasan Menonton Mahasiswa (Studi Pada Mahasiswa Ilmu Komunikasi Angkatan 2011-2012 ). " UNIB Schoolar Resitory ( Pusat Pengarsipan Data dan Karya Tulis Ilmiah Universitas Bengkulu, (2014): $1-30$.

10 Meiliani, Haryanti, Arcana, I Nyoman. "Pengembangan Youtube Pembelajaran Kedudukan Titik Terhadap Lingkaran di SMA
}

hiburan, terlihat dari banyaknya masyarakat di Indonesia yang menghasilkan karya produktif, baik karya seni maupun prestasi di bidang seni.

\section{Perkembangan Youtube bagi Mahasiswa}

Menurut Haryanti Meiliani, Youtube adalah video online dan yang utama dari kegunaan situs ini ialah sebagai media untuk mencari, melihat dan berbagi video yang asli dari segala penjuru dunia melalui suatu web. ${ }^{10}$ Youtube adalah sebuah situs web video sharing (berbagai video) populer dimana para pengguna dapat memuat, menonton, dan berbagi, klip video secara gratis. Umumnya video-video di Youtube adalah klip musik (video klip), film, TV, serta video buatan para penggunanya sendiri. Youtube telah banyak dikenal sebagian besar masyarakat di dunia terbukti ada banyak sekali channel youtube yang tersedia di youtube dan konten dari video tersebut. ${ }^{11}$ Situs ini memungkinkan pengguna mengunggah, menonton, dan berbagi video. Perusahaan ini berkantor pusat di San Bruno, California, dan memakai teknologi Adobe Flash Video dan HTML5 untuk menampilkan berbagai macam konten video buatan pengguna, termasuk klip film, klip TV, dan video musik. Selain itu ada pula konten amatir seperti blog video, video orisinal pendek, dan video

Menggunakan VideoScribe." UNION: Jurnal Pendidikan Matematika 7, No. 2 (2019):219-228.

11 P.H, Ektyani Dina. " Hate Speech Di Media Sosial (Studi Kasus Hate Speech Melalui Social Experiment V-Log Youtube Gita Savitri Devi "The Hate You Give”).” Jurnal VoxPop Ilmu Komunikasi UPN “Veteran" Jawa Timur, 1 No.1 (2019): 31-37 
Pendidikan. Sosial media adalah sebuah media online membantu individu dalam mendapatkan dan menyampaikan informasi seperti hal nya youtube yang di dukung dengan Perkembangan Youtube di Indonesia semakin pesat, Youtube menjadi salah satu platform atau media online paling populer saat ini. ${ }^{12}$ Popularitasnya diprediksi akan terus meningkat seiring dengan jumlah pengguna maupun pembuat konten. Youtube merupakan salah satu bentuk media sosial berbasis video yang mulai naik daun. ${ }^{13}$ Bahkan, lembaga riset pasar Statista memperkirakan jumlah penggunanya akan mencapai angka 1,8 miliar orang pada tahun 2021 di seluruh dunia. $^{14}$ Perkembangan Industri di Indonesia setelah adanya youtube membawa dampak yang sangat signifikan karena Industri Indonesia semakin kreatif, maju, inovatif serta menghasilan senimanseniman yang berkualitas.

\section{Konten Creator dalam Industri Kreatif}

Konten kreator adalah sebuah profesi membuat atau menciptakan sebuah konten baik berupa tulisan, gambar, video suara, animasi, dan lain sebagainya terlebih dahulu sudah di konsep dengan tujuan

12 Kamhar, Muhammad Yusi, Lestari, Erma. "Pemanfaat Sosial Media Youtube Sebagai Media Pembelajaran Bahasa Indonesia DI Perguruan Tinggi." INTELIGENSI: Jurnal Ilmu Pendidikan 1, No.2 (2019): 1-7.

13 David, Eribka Ruthellia, Sondakh, Mariam, Harilama, Stefi H. “ Pengaruh Konten Vlog dalam Youtube terhadap Pembentukan Sikap Mahasiswa Ilmu Komunikasi Fakultas Ilmu Sosial dan Politik Universitas Sam Ratulangi." Acta Diurna Komunikasi, 6 No.1 (2017): 3-18.

14 Saputri, Fiqih Hana. "Pembuatan Dokumenter Mengenai Keberhasilan Pemanfaatan Youtube Sebagai Mata Pencaharian Melalui Konten Kreatif."Jurnal Sisfotek Global, 10 No. 2 (2020): 12 tertentu baik untuk hiburan, informasi ataupun edukasi. Konten Creator biasanya berisi video yang dikhususkan untuk menarik perhatian penonton. ${ }^{15}$ Konten kreator di tuntut untuk kreatif tidak masalah untuk meniru karya seseorang "meniru" dalam konteks ini adalah meniru dan memodifikasi bukan di tiru dengan cara menjiplak mentah-mentah karya orang lain. Menurut Dionni Ditya Perdana Media massa saat ini bukan diperuntungkan untuk publik tetapi untuk idnsutri hiburan dan industi kreatif. ${ }^{16}$

\section{Persepsi}

Persepsi adalah proses penerimaan, pengevaluasian, menyeleksi dan menafsirkan gambaran serta informasi dan pemahaman tentang lingkungan, termasuk penetapan informasi unruk membentuk pengkategorian dan penafsirannya. Persepsi merupakan pengamatan (penyusunan dorongan-dorongan dalam kesatuan-kesatuan) hal mengetahui, melalui indera (tanggapan atau daya memahami). ${ }^{17}$ Intinya persepsi berkaitan dengan bagaimana seseorang menerima informasi dan menyesuaikan dengan lingkungannya. lni berarti adalah

15 Wati, Lina. "DRAMATURGI CONTENT CREATOR DALAM PRESENTASI DIRI DI INSTAGRAM (Studi Etnografi Virtual Pada akun Instagram @bangijal_tv).” DIALETIKA KOMUNIKA Jurnal Komunikasi dan Pembangunan Daerah 7, No.2 (2019): 12-21.

16 Ditya, Perdana Dionni. “ Komodifikasi Dalam Tayangan Televisi (Kajian Terhadap Program Indonesian Idol 2014). " Jurnal Professional FIS UNIVED 4 No.1 (2017): 12-21.

17 Siregar, Nina Siti Salmaniah. "Persepsi Orang Tua terhadap Pentingnya Pendidikan bagi Anak." Jurnal Ilmu Pemerintahan dan Sosial Politik UMA, 1 No.1 (2013): 11-27. 
interpretasi dalam memahami informasi yang dapat meningkatkan pengetahuan yang menerimanya atau adanya seleksi terhadap berbagai ransangan yang ditangkap oleh panca indra. Menurut Jalaludin, adalah pengalaman tentang objek, peristiwa, atau hubungan-hubungan yang diperoleh dengan menyimpulkan informasi dan menafsirkan pesan. ${ }^{18}$ Bagaimana cara persepsi bekerja dikarenakan persepsi bertautan dengan cara mendapatkan pengetahuan khusus tentang kejadian pada saat tertentu, maka persepsi terjadi kapan saja stimulus menggerakkan indera. Proses persepsi melalui tahapan-tahapan sebagai berikut: ${ }^{19}$ 1) Penerimaan rangsang, pada proses ini, individu menerima rangsangan dari berbagai sumber. Seseorang lebih senang memperhatikan salah satu sumber dibandingkan dengan sumber lainnya, apabila sumber tersebut mempunyai kedudukan yang lebih dekat atau lebih menarik baginya. 2) Proses menyeleksi rangsang, setelah rangsang diterima kemudian diseleksi disini akan terlibat proses perhatian. Stimulus itu diseleksi untuk kemudian diproses lebih lanjut. 3) Proses pengorganisasian, rangsang yang diterima selanjutnya diorganisasikan dalam suatu bentuk, 4) Proses penafsiran, setelah rangsangan atau data diterima dan diatur, si penerima kemudian menafsirkan data itu dengan berbagai cara. Setelah data tersebut dipersepsikan maka telah dapat dikatakan sudah terjadi persepsi. Karena

${ }^{18}$ Hadiwijaya, Hendra. "Persepsi Siswa Terhadap Pelayanan Jasa Pendidikan Pada Lembaga Pendidikan El Rahma Palembang." Jurnal Ekonomi dan Informasi Akuntasi (Jenius), 1 No. 3(2011): 218. persepsi pada pokonya memberikan arti kepada berbagai informasi yang diterima, 5) Proses pengecekan, setelah data ditafsir si penerima mengambil beberapa tindakan untuk mengecek apakah yang dilakukan benar atau salah. Penafsiran ini dapat dilakukan dari waktu ke waktu untuk menegaskan apakah penafsiran atau persepsi dibenarkan atau sesuai dengan hasil proses selanjutnya. 6) Proses reaksi, lingkungan persepsi itu belum sempurna menimbulkan tindakan-tindakan itu biasanya tersembunyi atau terbuka. Sebaliknya, bicara pesan sejatinya didapati melalui proses pemaknaan (meaning). ${ }^{20}$ Dalam konteks ini, simbol komunikasi yang baik dan tepat, ukurannya adalah bagaimana partisipan dapat memberikan fungsi dan maksud yang sama terhadap simbol tersebut. Pemaknaan sendiri adalah proses menemukan maksud dan arti sebuah pesan.

\section{Metode Penelitian}

Dalam penelitian ini, peneliti menggunakan metode penelitian kualitatif dengan menggunakan analisis audience yang bertujuan menjelaskan tentang "Persepsi Mahasiswa Mengenai Artis Televisi Yang Beralih Menjadi Youtube Conten Creator" dengan mewawancari 6 informan yang ada pada mahasiswa dengan mahasiswa yang bersedia menjawab pertanyaan peneliti, dan mahasiswa yang memiliki kemampuan untuk menjawab pertanyaan secara

19 Gorys Keraf, Komposisi: Sebuah Pengantar Kemahiran Bahasa, (Flores: Nusa Indah, 2004), 203

20 Nurjaman, Iman, Titi Rachmi, Arjulayana. "Persepsi Orang Tua Terhadap Pemerolehan Bahasa Inggris Anak Usia Dini”. Early Chilhood Jurnal Pendidikan 3, No. 2 (2019). 
komunikatif serta mahasiswa yang memiliki pengetahuan yang luas mengenai youtube. Waktunya melalui pengumpulan data wawancara mahasiswa Ilmu Komunikasi UPN Veteran Jawa Timur dan menggunakan jenis data Induktif. Peneliti menggunakan metode pengumpulan data dengan cara wawancara informan melalui aplikasi Zoom dan Whatsapp

\section{Hasil dan Pembahasan}

Dengan berkembangnya industri kreatif saat ini memunculkan para youtube konten kreator yang beragam dan sangat kreatif. Semakin majunya media youtube saat ini memberikan wadah bagi artis televisi di Indonesia dikarenakan banyaknya persaingan di dunia televisi yang semakin ketat karena di youtube dijadikan sebagi wadah untuk memperkenalkan identitas dan bisa menyampaikan ekspresi mereka melalui membuat konten pada channel youtubenya. Oleh karena itu, penelitian ini digunakan untuk mengetahui persepsi mahasiswa mengenai artis televisi yang beralih menjadi youtube konten kreator. Sehingga, pembaca dapat mengetahui perkembangan industri hiburan setelah adanya media youtube.

Seperti platform youtube yang merupakan bentuk kreatifitas masyarakat dan publik figure yang telah menjadi tayangan nomor satu di media sosial lain nya. Kaya akan informasi update dan mudah diakses dengan waktu yang relatif cepat. Karena pada saat ini, media konvesional sudah berkonvergensi ke media baru seperti contohnya membuat channel di youtube. Dari semua lapisan masyarakat saat ini sudah berkonvergensi.
Pada dasarnya masyarakat sekarang tidak tertarik dengan media konvensional tetapi bukan berarti media konvensional akan hilang.

Dalam youtube tidak ada gate keeper atau tidak mempunyai pengawasan serta pengontrolan dari segi informasi di dalamnya. Serta youtube bukanlah sebuah lembaga yang kebenarannya juga perlu dipertanyakan. Dibandingkan dengan televisi adalah media konvensional yang mana ia akan memberitakan berita-berita sosial media yang sering kita gunakan saat ini dan sebuah produk jurnalistik dibawah naungan KPI atau yang disebut dengan komisi penyiaran Indonesia. KPI mempunyai prosedur, birokrasi serta pengawasan tersendiri. Dapat diketahui dari hasil wawancara peneliti bahwa jawaban dari 6 mahasiswa yang menonton televisi hanya sebesar 2-3 jam saja bahkan terdapat mahasiswa yang sehari sama sekali tidak menonton berita yang terdapat dalam televisi. Dan dapat diketahui juga seberapa sering mahasiswa menonton youtube adalah sekitar 6 jam dalam 4 kali jumlah tontonan yang mereka lihat atau dapat dikatakan hampir setiap hari mahasiswa mengakses Youtube karena terdapat berbagai macam konten yang menghibur dan tidak membosankan.

Maka dari itu penulis, ingin membahas mengenai televisi sebagai industri yang dapat dipercaya untuk mendapatkan informasi yang lebih akurat dibandingkan media yang lainnya.

\section{Televisi sebagai Media Terpercaya untuk Medapatkan Berita}

Televisi adalah sistem media elektronik informasi menggunakan 
peralatan media yang mengubah cahaya dan suara ke dalam gelombang elektrik dan mengkonvegerensikan kembali sehingga dapat dilihat dan didengar, yang berada di dalam suatu lembaga industri penyiaran. Pemamparan Informan II sebagai mahasiswa ilmu komunikasi angkatan 2018 dalam memaknai Televisi sebagai media terpercaya untuk mendapatkan berita

"Aku lebih memilih televisi, kenapa kok televisi? karena televisi dia itu punya guide kepper, punya sesuatu yang ada penyaringan gitu, nggak langsung upload, dia punya prosedur sendiri”.

Informasi yang ditayangkan melalui televisi memiliki berita yang akurat, minim akan informasi hoax karena suatu informasi sebelum ditayangkan kepada khalayak akan melalui tahap gate keeper yang tugasnya menyeleksi informasi yang telah didapat, memastikan data yang baru saja didapat dan mengolah informasi secara intens agar meminimalisir adanya informasi hoax. Selain adanya gate keeper lembaga industri penyiaran juga berada dalam pengawasan Komisi Penyiaran Indonesia (KPI) yang berarti tidak bisa sembarangan memuat berita di televisi dan terdapat aturan dan batasan untuk menayangkan sebuah program yang ada di televisi.

\section{Berkurangnya Minat Mahasiswa terhadap Televisi}

Revolusi media memberikan dampak kepada kanal media tradisional kurang diminati banyak khalayak dikarenakan tayangan yang di tayangkan cenderung monoton dan membuat penonton bosan dan beralih ke media modern seperti youtube dikarenakan perkembangan media industri penyiaran cukup tertinggal jauh dibandingkan media youtube.

Selain itu televisi memiliki keterbatasan jam karena tidak semua mahasiswa memiliki waktu untuk menonton televisi setiap saat dan banyaknya aturan yang membuat penonton kurang tertarik ajakan tayangan pada televisi. Pemaparan oleh Informan I sebagai mahasiswa ilmu komunikasi mengenai minat mahasiswa berkurang terhadap televisi

"Sebenernya jika dilihat di televisi juga ada beberapa tayangan yang bernilai positif tapi ada beberapa tayangan yang kurang pas juga di tayangkan dan ditonton oleh masyarakat luas. Jadi menurut saya acara televisi saat ini kurang berbobot. Meskipun ada beberapa tayangan yang mengandung edukasi."

Informan II juga menjelaskan:

"Mungkin karena jenuh ya dengan konten konten televisi yang isinya itu-itu aja, terus konten yang ada di televisi kita nggak bisa milihkan karena apa yang ditunjukkan sama televisi mau nggak mau itu yang kita lihat dan kalo di youtube kita bisa memilih kita mau apa dan seperti apa dan juga konten-konten yang ada di youtube itu lebih fleksibel dan lebih kreatif dari pada di televisi yang dia mempunyai birokrasi yang menurutku lebih ribet.".

Seperti yang sudah disampaikan oleh dua informan bahwa televisi juga memiliki tayangan yang menarik namun tayangan membuat penonton kurang berbobot, selain itu tidak semua mahasiswa memiliki akses untuk menonton melalui televisi menurut mereka media yang mudah untuk di akses youtube, cukup melalui smartphone mahasiswa sudah dapat mengakses 
informasi melalui portal website yang bersitus daring seperti detik.com dan CNN yang memberikan informasi secara cepat serta akurat.

Mahasiswa cenderung melalui media youtube untuk mencari hiburan karena media youtube menawarkan banyak berbagai hiburan dan fitur yang dapat mempermudah penonton ketika mereka ingin menontonnya. Bahwa pada saat ini minat mahasiswa berkurang terhadap televisi dikarenakan kurangnya pilihan penayangan yang ada pada televisi yang artinya televisi kurang menyediakan konten kreatif serta harus menunggu jadwal tayang pada setiap stasiun televisi tanpa bisa di ulang kembali informasinya.

\section{Youtube sebagai Media Baru untuk Mengakses berbagai Konten}

Youtube merupakan media yang memfasilitasi penggunanya untuk menonton atau mengunggah suatu video. Youtube memiliki peran sebagai hiburan khusunya kepada generasi milenial saat ini yang menginginkan segala hal mudah dan efisien yang memiliki banyak kegunaan. Media youtube salah satu media yang memberikan informasi secara cepat, ketika media lain belum menyampaikan suatu inforrmasi youtube justru memberikan informasi yang update.

Pemaparan oleh Informan III sebagai mahasiswa ilmu komunikasi mengenai Youtube sebagai media baru untuk mengakses berbagai konten "Karena, Youtube kontennya sangat up to date inovatif dan mudah dijangkau. Sedangkan kita kan generasi milenial yang memegang hp kemanapun dimanapun setiap saat, lebih mudah mencari informasi." Seperti yang sudah dipaparkan oleh informan bahwa youtube digunakan sebagai hiburan khususnya bagi generasi milenial, konten variative, inovative serta tidak ada batas penayangan yang ada pada youtube membuat penonton lebih tertarik dengan konten yang ada pada youtube. Selain itu alasan banyak mahasiswa yang lebih menyukai youtube karena youtube sangat mudah digunakan dan dapat diakses kapan saja. Youtube merupakan media untuk penunjang keeksistensian mahasiswa dengan berbagai macam informasi di dalamnya. Youtube sebagai media untuk mengekspresikan diri atau menunjukan identitas, kesukaan, kegiatan sehari-hari dan untuk menyampaikan kritik. Bagi mahasiswa dengan cara mengunggah konten dengan ciri khas dan tema yang menarik.

\section{Kredibilitas Youtube}

Youtube merupakan media kemajuannya yang sangat pesat dari segi informasi maupun hiburan dan sangat diminati banyak orang yang saat ini. Namun dengan perkembangannya semakin pesat tidak sedikit orang yang menyalahgunakan media youtube, sehingga sebelum kita percaya dengan informasi yang ada di youtube sebagai penonton sebaiknya harus mencari tahu kebenaran dari informasi tersebut Pemaparan oleh Informan II sebagai mahasiswa ilmu komunikasi mengenai kelemahan youtube;

"Kalo di youtube secara garis besar atau secara luas itu rawan informasi hoax kalo bukan dari media yang terpercaya.".

Bahwa sangat perlunya sikap selektif dalam memilih suatu informasi dan dalam segi hiburan terkadang banyak sekali orang 
yang memiliki channel untuk membuat konten asal sehingga masih banyaknya konten mengandung sara yang di unggah melalui youtube membahayakan khusunya bagi anak yang kurang mendapat pengawasan dari orang tua membuat youtube menjadikan youtube media yang kurang kredibilitas, namun konten yang mengandung unsur sara, kekerasan atau pornografi pihak youtube akan mengambil tindakan untuk take down video tersebut.

\section{Preferensi pilihan Konten Youtube}

Semakin kreatifnya konten creator dalam membuat berbagai macam konten yang membuat para penonton lebih tertarik dengan youtube di bandingkan media yang lain, ketika terdapat suatu hal yang sedang trending youtube merupakan media alternatif yang digunakan untuk mencari tahu informasinya. Banyaknya konten saat ini mulai dari komedi, horror, beauty, travelling dan vlog (kehidupan personal tokoh).

Vlog merupakan salah satu konten yang diminati khusunya oleh khalayak karena penonton dari konten vlog kebanyakan fans dari seorang tokoh artis yang membuat channel youtube, dengan adanya fans tersebut dapat mendongkrak subscriber pada channel youtube tokoh tersebut. Pemaparan oleh Informan IV sebagai mahasiswa ilmu komunikasi mengenai Konten Youtube yang disukai;

"Konten yang aku sukain ketika nonton youtube itu nggak satu aja, misalnya podcatnya Deddy Corbuzier kan itu isinya informasi

\footnotetext{
${ }^{21}$ Kristanto, Bernald Realino Danu, Marta, Rustono Farady. "Monetisasi Dalam Strategi Komunikasi
}

terus ada pengetahuannya juga, yang dibahas juga luas terus sekarang juga nonton yang misteri misteri gitu."

Namun ketika dilihat dalam pandangan mahasiswa akan lebih tertarik pada konten podcast yang channelnya dimiliki oleh Deddy Cobuzier, podcast dari channel deddy berisikan tentang informasi yang disampaikan oleh narasumbernya sendiri ketika sedang trending karena narasumber akan diundang secara live oleh Deddy Corbuzier sehingga penonton dapat mengetahui fakta sesungguhnya.

\section{Persepsi Mahasiswa Mengenai Peralihan Artis Televisi menjadi Konten Creator}

Majunya teknologi yang sangat pesat menjadikan youtube sebagai media tempat bagi konten creator untuk mengembangkan inovasi dan menyalurkan kreativitasnya. YouTube merupakan salah satu malah merupakan yang terbesar di dunia maya. ${ }^{21}$

Selain itu youtube sebagai media eksistensi yaitu keberadaan media youtube memberikan kemudahan bagi khalayak dan khususnya kalangan generasi milenial saat ini yang minim untuk menyalurkan kreatifitasnya dalam membuat karya yang minim akan di tayangkan dalam industri penyiaran karena persaingan semakin ketat, dengan adanya youtube memberikan tempat para creator dan generasi milenial untuk menyalurkannya melalui media youtube supaya kreatifitas, identitas, keberadaan mereka tetap eksis dan diakui.

Lintas Budaya Bayu Skak Melalui Video Blog Youtube.” Jurnal Lugas, 3 No.1 (2019): 45-56. 
Bukan hanya konten creator namun banyaknya artis televisi yang beralih pada media youtube karena mengantsipasi ketika mereka sudah tidak dapat bertahan dalam industry pertelevisian. Peralihan artis televisi menjadi youtube konten creator adalah suatu hal yang wajar, seperti yang yang Pemaparan oleh Informan II sebagai mahasiswa ilmu komunikasi mengenai Persepsi Mahasiswa tentang artis yang berlaih menjadi Youtube Konten creator;

"Ya kalo menurut ku sah-sah aja kalo temen-temen tv pindah ke youtube karena memang dia punya massa di televisi. Jadi atas keberhasilan dia di televisi dia jadi punya power membuat channel dia itu bisa terangkat dan bisa menjadi youtuber. Mungkin kalo dari prespektifku sekarang kan pandemi, terus banyak dari peusahaan televisi komersial yang saat ini sedang irit atau memotong banyak budget dia supaya tetap berkreasi dan berproduksi".

Dijelaskan bahwa perlihan artis televisi ke youtube merupakan suatu hal yang wajar selama konten yang di sampaikan kepada khalayak masih pantas, Youtube juga memberikan Adsense yang menjanjikan kepada para creator yang aktif mengunggah video ke youtube dan di dukung dengan memiliki banyak subscriber. Walaupun youtube media yang sangat diminati oleh banyak mahasiswa namun untuk segi berita mahasiswa lebih memilih televisi karena informasi yang disampaikan melalui televisi telah melalui

22 Andriagus, Raja Tama. "Sistem Pendukung Keputusan Untuk Menentukan Kualitas Stasiun Televisi Sebagai Konsumsi Terbaik Bagi proses yang panjang dan sesuai dengan kaidah jurnalistik.

Menurut Raja Tama Andriagus banyaknya stasiun televisi saat ini membuat persaingan ketat antara stasiun televisi untuk berinovasi dalam membuat siaran-siaran yang menarik perhatian masyarakat guna mendapat rating tertinggi Namun sering kali karena ingin mengejar rating, banyak stasiun televisi yang kurang memperdulikan mutu dari siaran yang ditampilkannya. ${ }^{22}$ Sehingga berita yang di sampaikan lebih terpercaya dibandingkan youtube yang dianggap tidak memiliki kredibilitas dalam menyampaikan informasi secara faktual. Oleh karena itu, persepsi mahasiswa mengenai artis televisi yang beralih menjadi youtube konten kreator merupakan hal yang wajar serta didukung teknologi yang canggih maka artis televisi ini menjadikan youtube sebagai wadah untuk mencari penghasilan televisi, karena tidak semua artis dapat bertahan di industri televisi di Indonesia.

Dengan demikian persepsi mahasiswa mengenai artis televisi yang beralih menjadi youtube konten creator diatas menunjukkan bahwa perkembangan televisi saat ini mampu memberikan dampak secara positif bagi perkembangan industri penyiaran dari aspek informasinya. Dan mahasiswa dalam konteks informasi atau berita lebih memilih televisi dikarenakan minimnya informasi hoax karena, terdapat gate kepper yang mengantisipasi informasi yang tidak sesuai fakta.

Masyarakat Dengan Menggunkan Metode AHP.” Jurnal Teknologi Informasi, 1 No. 1,(2017):1-6 
Namun perkembangan televisi di dunia hiburan saat ini pada minat mahasiswa semakin menurun karena, program yang ditayangkan cenderung monoton, memiliki banyak aturan, dan penayangan yang terbatas. Sehingga, mahasiswa lebih memilih media lain seperti youtube karena perkembangan youtube pada saat ini sangatlah berpotensi sebagai tempat hiburan mahasiswa.

Sehingga, dengan beralihnya artis televisi menjadi youtube konten creator merupakan hal yang wajar untuk menampilkan dan memproduksi karya mereka di industri hiburan yang semakin berkembang. Namun dengan mudahnya orang mengakses youtube menjadikan banyaknya orang yang tidak bertangung jawab pada isi konten yang terdapat dalam channelnya. Maka dari itu mahasiswa harus lebih bijak dalam menggunakan media youtube

\section{Kesimpulan}

Dari penelitian dan pembahasan di atas maka dapat disimpulkan dengan persepsi mahasiswa mengenai banyaknya artis televisi yang beralih menjadi youtube konten kreator merupakan hal yang sangat wajar karena youtube digunakan sebagai wadah eksistensi diri, mengembangkan karya yang mereka punya. Selain itu juga sebagai wadah untuk menambah penghasilan dengan mengingat dunia televisi saat ini sangat mempunyai batasan, sehingga artis televisi tidak bisa bertahan lama di industri pertelevisian.

Dengan begitu para artis televisi yang berlatar belakang sebagai public figure dan ingin beralih pada platform youtube ini sangat diharapkan oleh para mahasiswa untuk memiliki isi konten yang berjiwa seni tanpa merusak ekosistem konten kreator yang sudah ada sejak dulu di youtube.

\section{Daftar Pustaka}

Atmoko, Andreas Dwi, Zainal Munir, dan Gilang Ramadhan. "Pengaruh Menonton Tayangan Televisi Terhadap Perilaku Agresif Pada Anak Prasekolah." Jurnal Keperawatan Profesional (JKP), 7 No.1 (2019): 110.

https://www.ejournal.unuja.ac.id/inde x.php/jkp/article/view/509

Ansyorie, Chairil, Azhar Marwan, dan Khairil Buldani. "Pengaruh Tayangan Talkshow "Indonesia Lawyers Club" Terhadap Pendidikan Politik Mahasiwa". Jurnal Professional FIS UNIVED, 6 No.2 (2019): 59-67. https://jurnal.unived.ac.id/index.php/p rof/article/view/945/790

P.H, Ektyani Dinda. "Hate Speech Di Media Sosial (Studi Kasus Hate Speech Melalui Social Experiment VLog Youtube Gita Savitri Devi "The Hate You Give")." Jurnal VoxPop Ilmu Komunikasi UPN "Veteran" Jawa Timur, 1 No.1 (2019): 31-37. http://voxpop.upnjatim.ac.id/index.ph p/voxpop/article/view/7

Faiqah, Fatty, Muh. Nadjib, dan, Andi Subhan Amir. "Youtube Sebagai Sarana Komunikasi Bagi Komunitas Makassarvidgram." Jurnal Komunikasi KAREBA, 5 No.2 (2016):259-272.

https://journal.unhas.ac.id/index.php/ kareba/article/view/1905

Fadhal, Soraya, dan Nurhajati Lestari. "Identifikasi Identitas Kaum Muda di Tengah Media Digital (Studi Aktivitas Kaum Muda Indonesia di Youtube)." Jurnal AL-AZHAR INDONESIA SERI PRANATA SOSIAL, 1 No.3 (2012): 176-200. 
https://jurnal.uai.ac.id/index.php/SPS/ .article/viewFile/60/47

Keraf, Gorys. Komposisi: Sebuah Pengantar Kemahiran Bahasa. Flores: Nusa Indah, 2004.

Hadiwijaya, Hendra. "Persepsi Siswa Terhadap Pelayanan Jasa Pendidikan Pada Lembaga Pendidikan El Rahma Palembang." Jurnal Ekonomi dan Informasi Akuntasi (Jenius), 1, no. 3 (September, 2011): 2-18. https://mpra.ub.unimuenchen.de/81588/

Meiliani, Haryanti, dan I Nyoman Arcana. "Pengembangan Youtube Pembelajaran Kedudukan Titik Terhadap Lingkaran di SMA Menggunakan VideoScribe." UNION: Jurnal Pendidikan Matematika 7, no. 2 (September, 2019): 219-228. https://doi.org/10.30738/union.v7i2.4 054

Saputri, Fiqih Hana, dan Koswara Dwiki Afrilian. "Pembuatan Dokumenter Mengenai Keberhasilan Pemanfaatan Youtube Sebagai Mata Pencaharian Melalui Konten Kreatif." Jurnal Sisfotek Global, 10, no. 2 (September, 2020): 1 6. http://dx.doi.org/10.38101/sisfotek .v10i2.292

Nurjaman, Iman, Titi Rachmi, dan Arjulayana. "Persepsi Orang Tua Terhadap Pemerolehan Bahasa Inggris Anak Usia Dini”. Early Chilhood Jurnal Pendidikan 3, no. 2 (November, 2019). https://journal.umtas.ac.id/index.php/ EARLYCHILDHOOD/article/view/5 $28 / 469$

Putra, Mardhan Kurniawan. "Pengaruh Tayangan Berita Jurnal Sore Di Esa Tv Terhadap Kepuasan Menonton Mahasiswa (Studi Pada Mahasiswa Ilmu Komunikasi Angkatan 20112012 )." Skripsi, UNIB Schoolar Resitory (Pusat Pengarsipan Data dan
Karya Tulis Ilmiah Universitas Bengkulu, (Januari, 2014): 1-30. http://repository.unib.ac.id/9219/1/I,II ,III,I-14-mar-FS.pdf

Winda, Makal. "Persepsi Orang Tua Tentang Tayangan Upin Ipin MNC TV Dalam Penggunaan Bahasa Melayu Pada Masyarakat Kelurahan Taratara 2 Kecamatan Tomohon Barat." Jurnal acta diurna komunikasi, 1 No.3 (2019): 1-12. https://ejournal.unsrat.ac.id/index.php /actadiurnakomunikasi/article/view/2 $5735 / 2538$

Ditya, Perdana Dionni. "Komodifikasi Dalam Tayangan Televisi (Kajian Terhadap Program Indonesian Idol 2014)." Jurnal Professional FIS UNIVED, 4, no.1 (Juni, 2017): 1221. https://doi.org/10.37676/professi onal.v4i1.446

Pratama, Deska Yoga, Ilham Mohammad Iqbal, dan Nadiem Attar Tarigan. "Makna Televisi Bagi Generasi Z." Inter Komunika: Jurnal Komunikasi 4, no. 1 (Juni, 2019): 88-103. https://www.neliti.com/publications/2 95628/makna-televisi-bagi-generasi-z

T.S, Andrea Prayoga dan Farid Rusdi. "Analisis Minat Pelanggan Konten Musik Video Pada Channel Youtube Eclat Story." Prologia, 2, no. 2 (Desember, 2018): 243-249. https://journal.untar.ac.id/index.php/p rologia/article/view/3583/2135

Rahayu, Puji Diah. "Persepsi Masyarakat Terhadap Etika Komunikasi Pembawa Acara Berita Tepian TV Dalam Memberikan Pesan Berita Kepada Masyarakat Seputar Kota Samarinda." e Journal Ilmu Komunikasi 3, no. 3, (2015): 185 198. https://ejournal.ilkom.fisipunmul.ac.i d/site/wpcontent/uploads/2015/08/eJo urnal-Dede\%20(08-21-15-02-4854).pdf. 
David, Eribka Ruthellia, Mariam Sondakh, dan Stefi Harilama. "Pengaruh Konten Vlog dalam Youtube terhadap Pembentukan Sikap Mahasiswa Ilmu Komunikasi Fakultas Ilmu Sosial dan Politik Universitas Sam Ratulangi." Acta Diurna Komunikasi, 6 No.1 (2017): 3-18. https://ejournal.unsrat.ac.id/index.php /actadiurnakomunikasi/article/view/1 5479

Kristianto, Bernard Realino Danu dan Rustono Farady Marta. "Monetisasi Dalam Strategi Komunikasi Lintas Budaya Bayu Skak Melalui Video Blog Youtube." Jurnal Lugas 3, no. 1 (Juni, 2019): 45-56. http://ojs.stiami.ac.id/index.php/lugas/ article/view/415

Fadhal, Soraya. " Identifikasi Kaum Muda Di Tengah Media Digital Studi Aktivitas Kaum Muda Indonesia di Youtube." Jurnal Al-Azhar Indonesia Seri Pranata Sosial 1, no. 3 (2012): 176-200 https://jurnal.uai.ac.id/index.php/SPS/ article/view/60.

Andriagus, Raja Tama. "Sistem Pendukung Keputusan Untuk Menentukan Kualitas Stasiun Televisi Sebagai Konsumsi Terbaik Bagi Masyarakat Dengan Menggunkan Metode AHP." Jurnal Teknologi Informasi 1, no. 1, (Maret, 2017): 1-6 http://www.jurnal.una.ac.id/index.php /jurti/article/download/45/42

Wati, Lina. "DRAMATURGI CONTENT CREATOR DALAM PRESENTASI DIRI DI INSTAGRAM (Studi Etnografi Virtual Pada akun Instagram @ bangijal tv).” DIALETIKA KOMUNIKA Jurnal Komunikasi dan Pembangunan Daerah 7, no. 2 (2019): 12-21. http://ejournal.unis.ac.id/index.php/D $\mathrm{K} /$ article/view/356
Kamhar, Muhammad Yusi dan Erma Lestari. "Pemanfaat Sosial Media Youtube Sebagai Media Pembelajaran Bahasa Indonesia DI Perguruan Tinggi." INTELIGENSI: Jurnal Ilmu Pendidikan 1, no. 2 (Desember, 2019): 1-7.

https://jurnal.unitri.ac.id/index.php/int eligensi/article/view/1356

Siregar, Nina Siti Salmaniah. "Persepsi Orang Tua terhadap Pentingnya Pendidikan bagi Anak." Jurnal Ilmu Pemerintahan dan Sosial Politik UMA 1, no. 1 (Juni, 2013): 11-27. http://www.ojs.uma.ac.id/index.php/j ppuma/article/view/548/877.

Saputri, Fiqih Hana. "Pembuatan Dokumenter Mengenai Keberhasilan Pemanfaatan Youtube Sebagai Mata Pencaharian Melalui Konten Kreatif." Jurnal Sisfotek Global 10, no. 2 (September, 2020): 12 https://www.ejurnal.ubk.ac.id/index.p hp/oratio/article/download/61/4317. 